to plant physiology]. Kiev: Naukova dumka [in Russian].

16. Epstein, E., Müller, J.-L. (1993). Indole-3-butyric acid in plants: occurrence, synthesis, metabolism and transport. Physiology Plantarum, 88, 382-389 [in English].

17. Guern, J., Peaud-Lenoel, C. (Eds.). (2012). Metabolism and molecular activities of cytokinins. New York: Springer Science \& Business Media [in English].
18. Kots, S.Ya., Volkogon, N.V., Grischuk, E.A. (2010). Sposobnost shtammov i Tn5-mutantov Bradyrhizobium japonicum $\mathrm{k}$ sintezu IUK i ABK in vitro [Ability of strains and Tn5-mutants of Bradyrhizobium japonicum to synthesize IAA and ABA in vitro]. Fiziologiya i biohimiya kulturnyih rasteniy - Physiology and biochemistry of cultivated plants, 42, 6 , 491-496 [in Russian].

\title{
ASSESSMENT OF SORPTION AND TOXICITY OF FLUOROQUINOLONE ANTIBIOTIC IN AGROECOSYSTEMS
}

\author{
L. Symochko
}

ДВНЗ «Ужсгородський національний університет»

\begin{abstract}
Наведено результати досліджень сорбиії антибіотика класу фторхінолонів - енрофлоксацину різними сільськогосподарськими культурами за внесення різної його концентрації у грунт: $1000 \mathrm{Mح}^{*} \mathrm{\kappa}^{-1} ; 100 \mathrm{M \nu}^{*} \mathrm{~K}^{-1} ; 10 \mathrm{M \nu}^{*} \mathrm{~K}^{-1}$. Експериментальні дослідження засвідчили, що активність поглинання антибіотика залежить від його концентрації у грунті і виду сільськогосподарської рослини. Встановлено, що найактивніше антибіотик поглинають Lactuca sativa var. Crispa i Calendula officinalis. Мінімальним уміст енрофлоксацину серед n'яти рослин був у Mentha piperita. Внесення у грунт енрофлоксацину в кониентрації 1000 мг`к2 $2^{-1}$ спричиняє формування високого рівня токсичності грунту. В модельних екосистемах з Thymus serpillum ma Mentha piperita токсичність грунту становила понад $70 \%$ в експериментах in vitro $i$ в середньому на $7 \%$ менше B-in vivo.
\end{abstract}

Ключові слова: енрофлоксацин, агроекосистема, фітотоксичність, антибіотик, сільськогосподарські рослини.

The fluoroquinolones are one of the most used classes of antibiotics. Enrofloxacin belongs to the class of fluoroquinolone antibiotics that have been intensively used for the treatment of bacterial infections in veterinary medicine. Once antibiotics enter the ecosystems, they can be treated as an ecological factor, driving the evolution of the community structure [1,2]. Accordingly, the change of community structure influences the ecological function of soil and water ecosystems such as biomass production and nutrient transformation. Indirect effects from the antibiotic disturbance to the micro-ecosystem are largely unknown, and it is expected that such disturbance might have significant and

(C) L. Symochko, 2017 long-term effects on the rate and stability of ecosystem functioning [3-5].

In the environment, enrofloxacin can undergo degradations by different processes including photolysis, biodegradation and oxidation by mineral oxides but it is not sensitive to hydrolysis. Despite these degradation mechanisms, environmental half life time of enrofloxacin is very long. This long environmental persistence of enrofloxacin can affect the growing of plant and the activity of the soil microbial communities.

As final products of metabolism, enrofloxacin and its metabolite ciprofloxacin end up in excrement [6,7]. Livestock manure is commonly used as organic fertilizer. One of its uses is on the fields where food plants are 
grown. The manure includes the residue of fluoroquinolones in addition to other drug residue. Plants can also intake fluoroquinolones along with minerals. The intake of drugs in small amounts can lead to drug resistance in pathogenic microbes and cause allergies and liver damage. Raw materials of animal origin are subject to strict state controls. There are no limits concerning raw materials of plant origin from agroecosystems. In the case of raw materials of plant origin, at state level only pesticide residues, nitrates, heavy metals are controlled, but not antibiotics.

The aim of this work has been to evaluate enrofloxacin phytotoxicity and uptake in crop plants by a multiple concentration test, controlling after fixed times (90 days) the effects of different concentrations.

\section{MATERIALS AND METHODS}

A feature of this work was the study of the sorption of enrofloxacin by crop plants. For this, the following plants were used as test objects: Lactuca sativa var. crispa, Anethum graveolens, Thymus serpillum, Mentha piperita, and Calendula officinalis. Based on the literature data, three model concentrations of enrofloxacin were selected for our studies: $1000 \mathrm{mg} \cdot \mathrm{kg}^{-1} ; 100 \mathrm{mg} \cdot \mathrm{kg}^{-1} ; 10 \mathrm{mg} \cdot \mathrm{kg}^{-1}$ in model agroecosystems. Studies were conducted in vivo and in vitro. Spiked soils were placed into nonporous plastic plant pots to give a total of 60 pots. This gave 3 replicates per compound with different concentration for assessing uptake by crop plants plus control. Each pot received 20 seeds. The plants were grown under controlled conditions in phyto-chamber: light intensity, 10000 lx with a 16/8 h light/dark cycle; humidity, $70 \%$; and temperature, $20^{\circ} \mathrm{C}$ during the light cycle and $15^{\circ} \mathrm{C}$ during the dark cycle. Plants were grown for 90 days. After this time, samples of plant material were removed from each pot, weighed, and placed in glass jars prior for analysis. The amount of enrofloxacin was determined in triplicate on each sample by High Performance Liquid Chromatography (HPLC). Enrofloxacin in plants was extracted according to the method of Palmada et al. [8]:
$250 \mathrm{mg}$ plants (dry weight) were extracted in $10 \mathrm{ml}$ acetonitrile containing 1\% acetic acid, then homogenized, sonicated (50), vortexed (10) and centrifuged (100) at $3000 \mathrm{~g}$. The supernatant was then collected and dried by nitrogen stream. The residue was suspended in $5 \mathrm{ml}$ phosphate buffer $\mathrm{pH}$ 7.4, defatted by a double liquid-liquid partition with $3+3 \mathrm{ml}$ $\mathrm{N}$-hexane followed by a double liquid-liquid partition with $3+3 \mathrm{ml}$ chloroform. The organic phases were pooled and dried by nitrogen stream. The residue was suspended in mobile phase and $50 \mu \mathrm{l}$ were injected into the HPLC. Phytotoxicity (\%) of soil in model ecosystems after 90 days of experiment was determined according to standard method with modification [9]. As test object was used lettuce (Lactuca sativa $\mathrm{L}$ ).

Results were expressed as means $( \pm)$ standard deviation $(\mathrm{SD})$ and $\left(\mathrm{SSD}_{05}\right)$ smallest significant differences of experiments were conducted in quadruplication. Data were evaluated using the software Statistica 7.0.

\section{RESULTS AND DISCUSSION}

Veterinary and human medicines are increasingly being monitored in slurry, soils, surface waters, and groundwaters. Therefore, concerns have been raised over the impacts of environmental exposure routes on human and environmental health [6].

In this study the potential for medicines to enter the food chain via uptake from soil into food plants was explored. The results demonstrate that following application of enrofloxacin to plants at environmentally realistic concentrations, selected substances are taken up at detectable levels.

Figure 1 shows the results of the accumulation of enrofloxacin by plants such as: $L a c$ tuca sativa var. crispa, Anethum graveolens, Thymus serpillum, Mentha piperita, Calendula officinalis.

The most active enrofloxacin from the soil was absorbed by Lactuca sativa var. crispa, and Calendula officinalis. When applied to the soil of enrofloxacin at concentration of $1000 \mathrm{mg} \cdot \mathrm{kg}^{-1}$ in the salad's phytomass its concentration was $60.71 \mathrm{mg} \cdot \mathrm{kg}^{-1}$ and in calendula $-49.03 \mathrm{mg} \cdot \mathrm{kg}^{-1}$. 


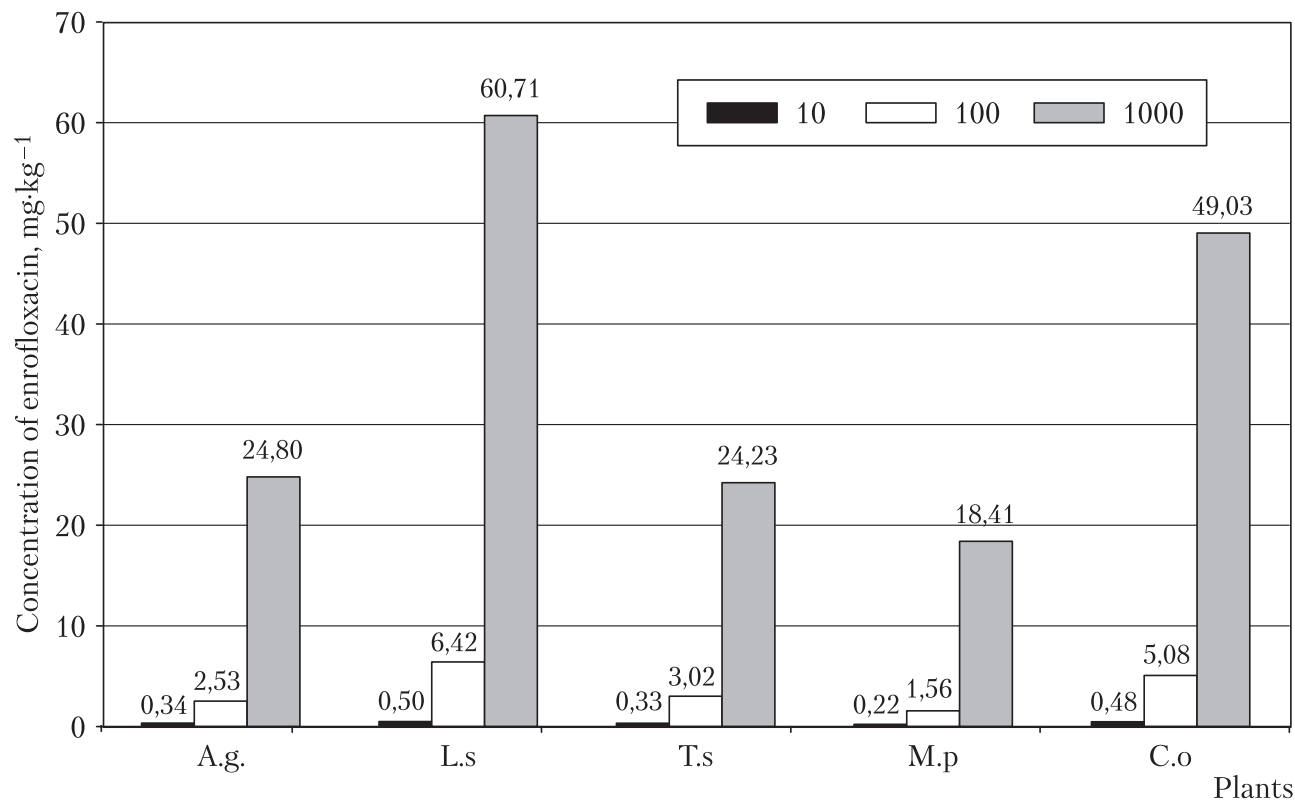

Accumulation of enrofloxacin by plants (applied it to soil in concentrations: $1000 \mathrm{mg} \cdot \mathrm{kg}^{-1}$; $100 \mathrm{mg} \cdot \mathrm{kg}^{-1} ; 10 \mathrm{mg} \cdot \mathrm{kg}^{-1}$ )

The lowest content of enrofloxacin was found in Mentha piperita with all three experimental concentrations of antibiotic in the soil. Experimental studies have shown that the Anethum graveolens and Thymus serpillum absorb antibiotic at the same level. At an experimental concentration of $10 \mathrm{mg} \cdot \mathrm{kg}^{-1}$ of antibiotic, its content after cultivation of 90 days was $0.34 \mathrm{mg} \cdot \mathrm{kg}^{-1}$ in Anethum graveolens, and in Thymus serpillum $0.33 \mathrm{mg} \cdot \mathrm{kg}^{-1}$, at concentration of enrofloxacin $1000 \mathrm{mg} \cdot \mathrm{kg}^{-1}$ its content in plants was significantly greater and were 24.80 and $24.23 \mathrm{mg} \cdot \mathrm{kg}^{-1}$. The results of the studies showed that there is a species differentiation of cultivated plants according to the activity of absorbing the antibiotic from the soil. Salad and calendula absorb the antibiotic the most actively, and mint was less active. Antibiotic effects on ecosystems are related to its concentration, bioavailability, exposure time and the addition of substrates. When antibiotics get into the arable land, they could possibly impact vegetation growth and development as well as soil microbial activity. Phytotoxicity of a chemical can be assayed using seed germination and plant growth tests. Limited studies have been conducted to investigate the phytotoxicity of some antibiotics to crop plants.

The biotesting demonstrated that antibiotics could negatively affect plant seed germination, but the effects varied between the plant species and between the concentrations of antibiotics used in the tests. Among the five plants, the high effect of toxicity in soil has been observed with cultivated Thymus serpillum and Mentha piperita.

As our studies showed, the toxicity of enrofloxacin in the soil in experiments in vivo was on average 10\% lower than in laboratory tests. The highest phytotoxic effect was observed in the soil of model ecosystems, where the concentration of enrofloxacin was $1000 \mathrm{mg} \cdot \mathrm{kg}^{-1}$. It should be noted that in the soil where Lactuca sativa was grown, the phytotoxic effect was $56.17 \%$ (in vitro) and $49.22 \%$ (in vivo). This is due to the active absorption of antibiotic by plants, which minimized the toxicity of the soil.

The different terrestrial toxicological effects of enrofloxacin were observed through using a series of bioassays and including sorp- 
Phytotoxicity (\%) of soil in model ecosystems after 90 days of experiment

\begin{tabular}{c|l|l|l|l|l|l|l}
\hline \multirow{2}{*}{ Plants } & \multicolumn{4}{|c|}{ In vitro } & \multicolumn{3}{c}{ In vivo } \\
\cline { 3 - 8 } & & \multicolumn{2}{|c|}{ Concentration of enrofloxacin } & \multicolumn{2}{c}{ Concentration of enrofloxacin } \\
\cline { 3 - 8 } & $1000 \mathrm{mg} \cdot \mathrm{kg}^{-1}$ & $100 \mathrm{mg} \cdot \mathrm{kg}^{-1}$ & $10 \mathrm{mg} \cdot \mathrm{kg}^{-1}$ & $1000 \mathrm{mg} \cdot \mathrm{kg}^{-1}$ & $100 \mathrm{mg} \cdot \mathrm{kg}^{-1}$ & $10 \mathrm{mg}^{*} \mathrm{~kg}^{-1}$ \\
\hline \hline 1 & Lactuca sativa & $56.17 \pm 1.31$ & $33.40 \pm 1.34$ & $22.43 \pm 1.29$ & $49.22 \pm 1.17$ & $30.10 \pm 1.22$ & $15.47 \pm 1.31$ \\
\hline 2 & $\begin{array}{l}\text { Calendula } \\
\text { officinalis. }\end{array}$ & $48.22 \pm 1.28$ & $28.32 \pm 1.18$ & $16.37 \pm 1.24$ & $43.67 \pm 1.07$ & $24.33 \pm 1.35$ & $12.30 \pm 1.13$ \\
\hline 3 & $\begin{array}{l}\text { Anethum } \\
\text { graveolens }\end{array}$ & $67.49 \pm 1.26$ & $46.88 \pm 1.11$ & $32.49 \pm 1.26$ & $60.42 \pm 1.32$ & $41.81 \pm 1.39$ & $25.99 \pm 1.45$ \\
\hline 4 & $\begin{array}{l}\text { Thymus } \\
\text { serpillum }\end{array}$ & $77.30 \pm 1.34$ & $55.99 \pm 1.29$ & $41.39 \pm 1.18$ & $70.39 \pm 1.44$ & $48.33 \pm 1.12$ & $37.34 \pm 1.44$ \\
\hline 5 & $\begin{array}{l}\text { Mentha } \\
\text { piperita }\end{array}$ & $71.47 \pm 1.09$ & $61.23 \pm 1.31$ & $38.43 \pm 1.22$ & $67.40 \pm 1.33$ & $55.22 \pm 1.37$ & $33.71 \pm 1.02$ \\
\hline
\end{tabular}

tion of fluoroquinolone antibiotic by five crop plants. Enrofloxacin is highly resistant, its biodegradation process is longer than other antibiotics, it is actively absorbed by the plants, and therefore it is necessary to control its content in phytoproducts.

\section{CONCLUSION}

The use of fluoroquinoline antibiotic on the farm leads to its accumulation in the soil, which is due to its long biodegradation. Experimental studies In vivo and In vitro have shown that the absorption activity of an anti- biotic depends on its concentration in the soil and the species of agricultural plants. Lactuca sativa and Calendula officinalis absorb enrofloxacin the most actively. The smallest content of enrofloxacin among five crop plants was in Mentha piperita. The high concentration of enrofloxacin in the soil causes significant phytotoxic effect. In model ecosystems with Mentha piperita and Thymus serpillum it was more than $70 \%$.

Acknowledgment. This work was supported by the Slovak Academic Information Agency (SAIA), grant number 18032.

\section{ЛІТЕРАТУРА}

1. Aminov R. Evolution and ecology of antibiotic resistance genes / R. Aminov, R. Mackie // FEMS Microbiol Lett. - 2007. - Vol. 271. - P. 147-161.

2. Migliore L. Phytotoxicity and uptake of enrofloxacin in crop plants / L. Migliore, S. Cozzolino, M. Fiori // Chemosphere. - 2003.- No. 52. - P. 1233-1244.

3. Thiele-Bruhn $S$. Effects of sulfonamide and tetracycline antibiotics on soil microbial activity and microbial biomass / S. Thiele-Bruhn, I. Beck // Chemosphere. - 2005. - No. 59. - P. 457-465.

4. Laboratory models to evaluate phytotoxicity of sulphadimethoxine on terrestrial plants / L. Migliore, C. Civitraele, S. Cozzolino et al. // Chemosphere. - 1998. - Vol. 37. - P. 2957-2961.

5. Alterations in soil microbial activity and N-transformation processes due to sulfadiazine loads in pig-manure / A. Kotzerke, S. Sharma, K. Schauss et al. // Environ Pollut. - 2008. - Vol. 153. - P. 315322 .
6. Uptake of Veterinary Medicines from Soils into Plants / A. Boxall, P. Johnson, E. Smith et al. // J. Agric. Food Chem. - 2006. - No. 54. - P. 2288-2297.

7. El-Mahmood A. Phytochemical screening and antibacterial evaluation of the leaf and root extracts of Cassia alata Linn / A. El-Mahmood, J. Doughari // Afr J Pharm Pharacol. - 2008. - No. 2. P. $124-129$.

8. Determination of enrofloxacin and its active metabolite (ciprofloxacin) at the residue level in broiler muscle using HPLC with fluorescence detector / J. Palmada, R. March, E. Torroella et al. // Proceedings of Euroresidue IV. Residues of Veterinary Drugs in Food. ADDIX, Wijk bij Duurstede. Netherlands, 2000. - P. 822-826.

9. Wang $W$. Root elongation method for toxicity testing of organic and inorganic pollutants / W. Wang // Environ. Toxicol. Chem. - 1987. - No. 6. P. 409-414. 


\section{REFERENCES}

1. Aminov, R., Mackie, R. (2007). Evolution and ecology of antibiotic resistance genes. FEMS Microbiol Lett, 271, 147-161 [in English].

2. Migliore, L., Cozzolino, S, Fiori, M. (2003). Phytotoxicity and uptake of enrofloxacin in crop plants. Chemosphere, 52, 1233-1244 [in English].

3. Thiele-Bruhn, S., Beck I. (2005). Effects of sulfonamide and tetracycline antibiotics on soil microbial activity and microbial biomass. Chemosphere, 59, 457-465 [in English].

4. Migliore, L., Civitraele, C., Cozzolino, S., Casoria, P., Brambilla, G., Gaudio, L. (1998). Laboratory models to evaluate phytotoxicity of sulphadimethoxine on terrestrial plants. Chemosphere, 37, 2957-2961 [in English].

5. Kotzerke, A., Sharma, S., Schauss, K., Heuer, H., Thiele-Bruhn, S., Smalla, K., Wilke, BM., Schloter, M. (2008). Alterations in soil microbial activity and $\mathrm{N}$-transformation processes due to sulfadiazine loads in pig-manure. Environ Pollut, 153, 315-322 [in English].
6. Boxall, A., Johnson, P., Smith, E., Sinclair, C., Stutt, E., Levy, L. (2006). Uptake of Veterinary Medicines from Soils into Plants. J. Agric. Food Chem, 54, 2288-2297 [in English].

7. El-Mahmood, A., Doughari, J. (2008). Phytochemical screening and antibacterial evaluation of the leaf and root extracts of Cassia alata Linn. Afr.J. Pharm. Pharacol., 2, 124-129 [in English].

8. Palmada, J., March, R., Torroella, E., Espigol, C., Baleri, T. (2000). Determination of enrofloxacin and its active metabolite (ciprofloxacin) at the residue level in broiler muscle using HPLC with fluorescence detector. Proceedings of Euroresidue IV. Residues of Veterinary Drugs in Food. Netherlands: ADDIX, Wijk bij Duurstede [in English].

9. Wang W. (1987). Root elongation method for toxicity testing of organic and inorganic pollutants. Environ. Toxicol. Chem, 6, 409-414 [in English].

\section{ПОВІДОМЛЕННЯ}

\section{НОВИНИ}

12 вересня 2017 р. в Інституті агроекології і природокористування НААН відбулося засідання круглого столу на тему: «Біогеохімія мікроелементів в агроландшафтах». У роботі круглого столу взяли участь 26 фахівців, які представляли різноманітні напрями біогеохімічних досліджень мікроелементів на землях сільськогосподарського призначення України, що проводяться Національною академією аграрних наук України, Національною академією наук України, Міністерством екології і природних ресурсів України та Міністерством аграрної політики та продовольства України.

У рамках доповідей обговорено актуальні питання теорії і практики біогеохімічних досліджень, серед яких: значення біогеохімічного вчення В.I. Вернадського для агроекологічних досліджень, вплив мікроелементів на живлення сільськогосподарських культур, екологічна геохімія промислових та сільськогосподарських ландшафтів, екстракція важких металів сільськогосподарськими культурами, біогеохімічний дисбаланс поживних мікроелементів як чинник ендемічної захворюваності населення України, агроекологічне значення геолого-геохімічних досліджень орних земель та промислових ландшафтів.

У прийнятій резолюції круглого столу підкреслено такі аспекти:

1. Біогеохімічне вчення В.І. Вернадського є теоретичною і методологічною основою вивчення хімічного складу сільськогосподарських культур як живої речовини у складі єдиної системи «вода - гірські породи - грунти - рослина».

2. Агроландшафтне районування земель сільськогосподарського призначення та прилеглих територій є методологічною основою для узагальнення і аналізу матеріалів агрохімічного моніторингу грунтів. Доцільним є відновлення структурних підрозділів екологічної інспекції у межах земель сільськогосподарського призначення.

3. 3 метою підвищення рівня наукового обгрунтування агроекологічного оцінювання земель необхідно проводити спільні дослідження системи «грунт - сільськогосподарська культура» та застосовувати кількісні показники біогеохімічного стану грунтів і вод. 